\title{
Measuring Pitchers' Performance Using Data Envelopment Analysis with Advanced Statistics
}

\author{
Shihteng Chiu \\ Stella Maris Primary School, Taiwan \\ E-Mail: jerrychiu918@gmail.com \\ Chiahuei Hsiao \\ National Taipei University \\ E-Mail: eva3388168@gmail.com \\ Huichin $\mathrm{Wu}$ \\ National Taipei University \\ E-Mail: elaine@mail.ntpu.edu.tw
}

\begin{abstract}
This paper evaluates starting pitchers' pitching performance during the 2008 to 2014 Major League Baseball (MLB) seasons. We use data envelopment analysis (DEA) based on two inputs (i.e., innings pitched [IPs] and per pitched innings) and three outputs (fielding independent pitching, earned run average [ERA], and skill-interactive ERA) to evaluate the performance of the 30 MLB teams' starting pitchers with IPs greater than 200 in each single season (2008 to 2014, regular season only). We used the CCR models to calculate the overall efficiency, scale efficiency, technical efficiency, efficiency value, and the slack analysis to measure a pitcher's performance in each single season. The results showed that $4,3,4,3,5,3$, and 5 pitches reached overall efficiency each year, from 2008 to 2014 (regular season). By analyzing the results and computing performance indexes and benchmarks for each starting pitcher, we determine the true value of each player to help baseball teams select highly indexed players and maximize player efficiency.
\end{abstract}

Keywords: Advanced Statistics, Pitchers, Data Envelopment Analysis, Innings Pitched, Earned Run Average 


\section{INTRODUCTION}

Competitive sports interest a large number of people who watch them because of their uncertainty and unpredictability. Kao (2011) showed that the sports stars and the records in the games are the most important factors to spectators. In addition, professional sports represent a highly competitive battlefield characterized by the survival of the fittest. The games always focus on players' actual strengths and accomplishments. Thus, victory is certainly related to a player's individual performance.

Over time, the game of baseball has become increasingly complex. With the gradual improvement in baseball players' stamina and skill and increasingly varied game strategies, the division of labor in the tournament is becoming more delicately balanced. Specifically, the pitcher plays an important role in baseball. The performance of the pitcher can be crucial to the outcome of a game (Kindall, 1993; Lopez, A., \& Kirkgard, J., 1996; Yeh, Lee, \& Zhu, 2003).

However, how can we judge the pitcher's performance? Can we determine the pitcher's efficiency and "concretize" the results? The statistics we always hear are the earned run average (ERA) and walks plus hits per inning pitched (WHIP). Henry Chadwick defines ERA as the mean of earned runs given up by a pitcher per nine innings pitched. We determine the ERA by dividing the number of earned runs allowed by the number of innings pitched and multiplying the result by nine. Runs resulting from defensive errors (including pitchers' defensive errors) are recorded as unearned runs and are not used to determine ERA. Meanwhile, the WHIP was invented in 1979 by Daniel Okrent. In baseball statistics, the WHIP is a sabermetric measurement of the number of base runners a pitcher has allowed per inning pitched. Since the WHIP reflects a pitcher's propensity for allowing batters to reach a base, a lower WHIP indicates a better performance. We calculate the WHIP by adding the number of walks and hits allowed and dividing this sum by the number of innings pitched.

Because of the complexity of baseball, traditional statistics cannot provide a comprehensive measure of the pitcher's performance; however, advanced statistics can be credited with such a measure. Bradbury (2007) used multiple regression analysis to analyze the factor of lost points; the results showed that the pitcher's ability contributes about $73 \%$ and the defense's ability accounts for about $27 \%$ of the game's outcome. Thus, the ERA does not wholly reflect the pitcher's ability.

For example, when a runner is on base, if the relief pitcher cannot help the starting pitcher hold the runner on the base until the end of the inning, the runner will make a run or runs that affect the starting pitcher's ERA rather than the relief pitcher's ERA. This means the ERA is affected by not only the starting pitcher's, but also every other 
pitcher's ability. Meanwhile, the teammates' defense ability also affects the ERA and WHIP.

Therefore, the selective use of statistics to judge whether or not a pitcher performs well is bound to create bias. This explains the creation of advanced statistical metrics, such as fielding independent pitching (FIP). The 2009 American League Cy Young Award winner Zach Greinke won over the rivals using the FIP, created by Tom Tango in 2008: "That's pretty much how I pitch, to try to keep my FIP as low as possible" (Kenper, 2009). Meanwhile, 1974-2008 MLB data showed that FIP is the metric that most likely reflects the pitcher's real ability (Piette, Braunstein, McShane, \& Jensen, 2010). Therefore, we seek to address the weak points of ERA and WHIP through advanced statistics, such as FIP and skill-interactive ERA (SIERA). We introduce these two statistics in the following subsections.

\section{Fielding Independent Pitching}

In 1999, Voros McCracken analyzed a record called Defense-Independent Pitching Statistic (DIPS), which is not affected by the team's defense. McCracken outlined a better way to assess a pitcher's talent level by looking at the results a pitcher can control: strikeouts, walks, hit by pitches, and home runs. Aiming to better evaluate pitchers in light of his theory, McCracken developed the Defense-Independent ERA (dERA), the most well-known DIPS. However, McCracken's formula for dERA is very complicated, with a number of steps.

Compared to DIPS, FIP can easily show what a pitcher's ERA should have looked like over a given time period, assuming that performance on balls in play and timing were in accordance with the league average. A walk is probably not as harmful as a home run, and a strikeout has less impact than both. FIP accounts for these kinds of differences, presenting the results on the same scale as ERA; it has been shown to be more effective than ERA in terms of predicting future performance and has become a mainstay in sabermetric analysis.

Tom Tango created a matrix in 2008 with run values for each play outcome. The coefficients attempt to adjust for how much each home run or each walk contributes to the other team's runs scored and how much each strikeout contributes to preventing the other team's runs scored.

$$
\frac{\{(13 * H R)+[3 *(B B+H B P)]-(2 * K)\}}{I P}+\text { constant }
$$




\section{Skill-Interactive era}

Skill-interactive ERA (SIERA) is the latest in a long line of ERA estimators. Like its predecessor, FIP, SIERA attempts to determine the underlying skill level of the pitchers and how well they actually pitched over the past year-namely, should their ERA have been higher or lower, or was it about right? SIERA does not ignore balls in play, but attempts to explain why certain pitchers are more successful at limiting hits and preventing runs. The strength of SIERA is that it tells us more about the how and why of pitching.

SIERA was developed by Eric Seidman and Matt Swartz. Unlike FIP, SIERA looks at not only home run (HR), hit by pitch (HBP), base on balls (BB), and strikeout (SO), but also ground balls (GB) and fly balls (FB). The coefficients are provided in Table 1.

Table 1 SIERA coefficients

\begin{tabular}{ll}
\hline Variable & SIERA coefficient \\
\hline$(\mathrm{SO} / \mathrm{PA})$ & $\mathbf{- 1 5 . 5 1 8}$ \\
$(\mathrm{SO} / \mathrm{PA})^{\wedge} 2$ & $\mathbf{9 . 1 4 6}$ \\
$(\mathrm{BB} / \mathrm{PA})$ & $\mathbf{8 . 6 4 8}$ \\
$(\mathrm{BB} / \mathrm{PA})^{\wedge} 2$ & 27.252 \\
$($ netGB/PA) & $\mathbf{- 2 . 2 9 8}$ \\
$+/-(\mathrm{netGB} / \mathrm{PA})^{\wedge} 2$ & $\mathbf{- 4 . 9 2 0}$ \\
$(\mathrm{SO} / \mathrm{PA})^{*}(\mathrm{BB} / \mathrm{PA})$ & -4.036 \\
$(\mathrm{SO} / \mathrm{PA})^{*}($ netGB/PA) & 5.155 \\
$(\mathrm{BB} / \mathrm{PA})^{*}($ netGB/PA) & 4.546 \\
Constant & $\mathbf{5 . 5 3 4}$ \\
Year coefficients $($ versus 2010$)$ & From -0.020 to +0.289 \\
\% innings as SP & $\mathbf{0 . 3 6 7}$ \\
\hline
\end{tabular}

Source: Fangraphs.com

Note: SO (strike out); PA (plate appearances); BB (base on balls); GB (ground balls); SP (starting pitcher)

Statistics are also important to the baseball team. The book MoneyBall mentions that the Oakland Athletics team uses data analysis to determine which players it needs (Lewis, 2004). Similarly, the Tampa Bay Rays recently used the same method to improve team efficiency (Keri, 2011). In terms of performance appraisal, the data 
envelopment analysis (DEA) was applied in evaluate the National Football League (NFL) players' performance (Leibenstein \& Maital, 1992), and Howard and Miller (1993) applied it to evaluate the relationship between MLB players' defense performance and salary.

Charnes, Cooper, and Rhodes mentioned the DEA in 1978; the idea originated from productive efficiency, which Farrell first discussed in 1957. Following this, Anderson and Sharp (1997) used DEA to analyze the MLB batters' attack performance, and Sexton and Lewis (2003) examined the manage performance in the MLB. More recently, Chen and Johnson (2010) used the DEA to analyze the dynamics of performance in MLB from 1871 to 2006. These studies have demonstrated that the DEA is a useful tool for analyzing performance in sports.

According to Lewis, Lock, and Sexton's (2009) results, professional baseball teams can split two ways - namely, players' abilities and performance - to promote the team's winning rate by efficiency programs. In terms of performance, Lin (2004) used the DEA to analyze the pitcher's performance in the Chinese Professional Baseball League (CPBL) and offer some suggestions to enhance the pitcher's performance.

As previously mentioned, baseball statistics are important to not only players, but also teams and fans. In this paper, we use DEA, an advanced statistical technique, to evaluate the starting pitcher's efficiency. This tool helps starting pitchers adjust among themselves and allow the team to choose the starting pitchers they need. Hence, our goals in this paper are two-fold:

1. To evaluate the MLB starting pitchers' performance in 2013.

2. To identify the areas that each starting pitcher needs to enhance.

\section{METHODOLOGY}

The Cy Young Award is the pitcher's highest honor, and the winner is voted on by the Baseball Writers Association of America (BBWAA). From 2000 to 2013, the pitchers who won the award had an IP greater than 200. Therefore, we selected all 30 MLB teams' starting pitchers whose IP is greater than 200 as the decision-making units (DMUs).

\section{Data}

We collected the data from the MLB's official website (http://www.mlb.com), Baseball-Reference.com (http://www.baseball-reference.com), and so on. The data include ERA, FIP, SIERA, pitches per inning pitched (P/IP), and IP. As stated by Golany and Roll (1989), DEA evaluates a group of comparable units' relative 
efficiency. Unlike for the batter, a lower value is better for the pitcher. Therefore, we change the ERA, FIP, and SIERA values to their reciprocals.

\section{The DEA Technique}

DEA was introduced to measure the relative efficiency of the DMUs that change inputs into outputs (Charnes, Cooper, \& Rhodes, 1978). The DEA model has become a very popular management tool to measure performance in many kinds of industries, and it has proven to be a very good tool in many research studies (Lee, Shih, \& Huang, 2011; Lin, 2010; Sexton \& Lewis, 2003; Tsai \& Chao, 2009). The DEA technique was originated by Farrell, the progenitor of the productive efficiency concept (Charnes, Cooper, \& Thrall, 1991). Farrell assumed constant returns to scale in terms of a volume production curve that illustrates the relationship between the actual use of the observation point and the yield curve, such as the border, in order to achieve a technical efficiency size.

In this case, we used Cooper, Seiford, and Tone's (1999) concept; these researchers proposed the Charnes, Cooper, and Rhodes (CCR) and Banker, Charnes, and Cooper (BCC) models. The CCR model uses constant returns scale (CRS) to evaluate the overall efficiency (OE). The BCC model uses variable returns to scale (VRS), in place of CRS in the CCR model, to evaluate technical efficiency (TE) and scale efficiency (SE). Thus, these statistics provide reference points for efficiency improvement based on the individual decision-making unit's returns to scale.

\section{Analyses}

We collected all MLB teams' starting pitchers who reached 200 IP during the 2008 to 2014 regular seasons, resulting in about 30 to 45 starting pitchers in each year for the DMUs in this research. Considering that this paper aims to determine the starting pitcher's performance, we evaluated the performance rate with the chosen IP and P/IP for the input and the reciprocals of the ERA, FIP, and SIERA for the output. Because calculating the IP requires making 3 outs for 1 IP, and the 1 out equates to $1 / 3$ IP, we make 0.1 IP for 0.33 and 0.2 IP for 0.67 to analyze the data correctly. Finally, we used DEAP 2.1 to analyze all the data collected. 


\section{RESULTS}

\section{Data Inspection}

We used SPSS 20.0 to calculate the Pearson correlation coefficient to determine the relationship between inputs and outputs; the results are shown in Tables 2 and 3.

Table 2 Input Correlation Matrix

\begin{tabular}{lll}
\hline & IP & P/IP \\
\hline IP & 1 & $.886^{* *}$ \\
$\mathrm{P} / \mathrm{IP}$ & $.886^{* *}$ & 1 \\
${ }^{* *} p<.01$ &
\end{tabular}

Table 3 Output Correlation Matrix

\begin{tabular}{llll}
\hline & $1 /$ ERA & $1 /$ FIP & $1 /$ SIERA \\
\hline 1/ERA & 1 & $.846^{* *}$ & $.767^{* *}$ \\
$1 /$ FIP & $.846^{* *}$ & 1 & $.906^{* *}$ \\
$1 /$ SIERA & $.767^{* *}$ & $.906^{* *}$ & 1 \\
\hline${ }^{* *} p<.01$ & & &
\end{tabular}

The results of the Pearson correlation analysis showed a positive correlation between IP and P/IP $(p<.01)$ and among 1/ERA, 1/FIP, and 1/SIREA $(p<.01)$. Sun (2004) maintained that a determinant relationship among all variables is a necessary condition for performance evaluation. Accordingly, we reserved all variables for this paper.

\section{Mlb 2008-2014 Statistics on Starting Pitchers}

Table 4 to Table 8 present the DMUs' input and output data collected from the MLB official website, Fangraphs, and the ESPN website.

The maximum IP pitched was CC Sabathia's 253 IP in the 2008 regular season; the maximum P/IP pitched was Ryan Dempster's 17.37 P/IP in the 2011 regular season. The best performances were those by Clayton Kershaw at 1/ERA pitched in the 2013 regular season, Roy Halladay at 1/FIP pitched in the 2011 regular season, and Felix Hernandez at 1/SIERA pitched in the 2014 regular season. 
Table 4 The Maximum IP of MLB 2008-2014 Season's Starting Pitchers

\begin{tabular}{lccccccc}
\hline & 2008 & 2009 & 2010 & 2011 & 2012 & 2013 & 2014 \\
\hline Maximum & 253 & 240 & 250.67 & 251 & 238.33 & 241.67 & 248.33 \\
DMUs & CC. & Justin & Roy & Justin & Justin & Adam & David \\
& Sabathia & Verlander & Halladay & Verlander & Verlander & Wainwright & Price \\
\hline
\end{tabular}

Table 5 The Maximum P/IP of MLB 2008-2014 Season's Starting Pitchers

\begin{tabular}{lccccccc}
\hline & 2008 & 2009 & 2010 & 2011 & 2012 & 2013 & 2014 \\
\hline Maximum & 17.55 & 17.07 & 16.87 & 17.37 & 17.05 & 17.19 & 16.94 \\
DMUs & Justin & Doug & C. J. & Ryan & Yovani & C.J. & Lance \\
& Verlander & Davis & Wilson & Dempster & Gallardo & Wilson & Lynn \\
\hline
\end{tabular}

Table 6 The Best 1/ERA of MLB 2008-2014 Season's Starting Pitchers

\begin{tabular}{lccccccc}
\hline & 2008 & 2009 & 2010 & 2011 & 2012 & 2013 & 2014 \\
\hline Maximum & .395 & .463 & .441 & .439 & .395 & .546 & .467 \\
DMUs & Johan & Zack & Felix & Clayton & Clayton & Clayton & Felix \\
& Santana & Greinke & Hernandez & Kershaw & Kershaw & Kershaw & Hernandez \\
\hline
\end{tabular}

Table 7 The best 1/FIP of MLB 2008-2014 season's starting pitchers

\begin{tabular}{lccccccc}
\hline & 2008 & 2009 & 2010 & 2011 & 2012 & 2013 & 2014 \\
\hline Maximum & .386 & .429 & .388 & .455 & .352 & .418 & .426 \\
DMUs & Tim & Zack & Cliff & Roy & Felix & Clayton & Corey \\
& Lincecum & Greinke & Lee & Halladay & Hernandez & Kershaw & Kluber \\
\hline
\end{tabular}

Table 8 The best 1/SIERA of MLB 2008-2014 season's starting pitchers

\begin{tabular}{lccccccc}
\hline & 2008 & 2009 & 2010 & 2011 & 2012 & 2013 & 2014 \\
\hline Maximum & .319 & .350 & .347 & .369 & .326 & .362 & .400 \\
DMUs & Tim & Javier & Roy & Cliff & Cliff & Yu & Felix \\
& Lincecum & Vazquez & Halladay & Lee & Lee & Darvish & Hernandez \\
\hline
\end{tabular}




\section{Performance of DMUS}

Table 9 shows the maximum and minimum performances among MLB starting pitchers from 2008 to 2014 in terms of overall efficiency (OE). Table 10 shows the numbers sorted by Norman and Stocker (1991); the TE values are separated into E (TE $=1), \mathrm{F}(.90 \leqq \mathrm{TE}<1)$, and $\mathrm{G}(\mathrm{TE}<.90)$.

Table 9 The abstract of MLB 2008-2014 Regular Season DMUs’ Performance

\begin{tabular}{|c|c|c|}
\hline & DMUs of Maximum OE & DMUs of Minimum OE \\
\hline 2008 & $\begin{array}{l}\text { Tim Lincecum } \\
\text { Cliff Lee } \\
\text { CC Sabathia } \\
\text { Dan Haren } \\
\text { Roy Halladay }\end{array}$ & Scott Olsen (.693) \\
\hline 2009 & $\begin{array}{l}\text { Zack Greinke } \\
\text { Tim Lincecum } \\
\text { Javier Vazquez }\end{array}$ & $\begin{array}{c}\text { Bronson Arroyo } \\
(.621)\end{array}$ \\
\hline 2010 & $\begin{array}{l}\text { Cliff Lee } \\
\text { Adam Wainwright } \\
\text { Justin Verlander } \\
\text { Roy Halladay } \\
\text { Felix Hernandez }\end{array}$ & Randy Wolf (.674) \\
\hline 2011 & $\begin{array}{l}\text { Roy Halladay } \\
\text { Clayton Kershaw } \\
\text { Cliff Lee }\end{array}$ & Carl Pavano (.662) \\
\hline 2012 & $\begin{array}{l}\text { Felix Hernandez } \\
\text { Clayton Kershaw } \\
\text { David Price } \\
\text { Cliff Lee } \\
\text { R.A. Dickey }\end{array}$ & Jason Vargas ( .702) \\
\hline 2013 & $\begin{array}{l}\text { Clayton Kershaw } \\
\text { Felix Hernandez } \\
\text { Cliff Lee }\end{array}$ & $\begin{array}{l}\text { Jeremy Guthrie } \\
(.617)\end{array}$ \\
\hline 2014 & $\begin{array}{l}\text { Corey Kluber } \\
\text { Felix Hernandez } \\
\text { Stephen Strasburg } \\
\text { Zack Greinke } \\
\text { Cole Hamels }\end{array}$ & R.A. Dickey (.664) \\
\hline
\end{tabular}


Table 10 The Numbers of the Technical Efficiency Sort in 2008-2014 MLB Season

\begin{tabular}{lccccccc}
\hline & 2008 & 2009 & 2010 & 2011 & 2012 & 2013 & 2014 \\
\hline $\mathrm{E}(\mathrm{TE}=1)$ & 11 & 10 & 14 & 11 & 8 & 10 & 11 \\
$\mathrm{~F}(.90 \leqq \mathrm{TE}<1)$ & 6 & 3 & 5 & 7 & 8 & 7 & 7 \\
$\mathrm{G}(\mathrm{TE}<.90)$ & 14 & 22 & 26 & 21 & 14 & 19 & 15 \\
\hline
\end{tabular}

\section{Slack Variable Analysis of TE in sort "F" in The VRS Model}

In the VRS model, the sort F refers to TE values between .90 and 1, as shown in Tables 11 and 12. We used Zack Grienke $(\mathrm{TE}=.980)$ and Justin Verlander $(\mathrm{TE}=.987)$ in 2012 as examples. In 2012, when Grienke held his IP at 220.00 and lowered P/IP to 14.07, he raised his 1/ERA to $.333,1 /$ FIP to .377 , and 1/SIERA to .329; thus, his TE value equals 1 . Meanwhile, Verlander needed to improve his performance by lowering his IP to 226.79 and P/IP to 15.16 and raising his 1/ERA from .379 to $.384,1 / \mathrm{FIP}$ from .340 to .345 , and 1/SIERA from .300 to .304 to achieve a TE of 1 .

Table 112012 Zack Grienke Slack Variable Analysis

\begin{tabular}{llccccc}
\hline & Technical Efficiency & IP & P/IP & 1/ERA & 1/FIP & 1/SIERA \\
\hline \multirow{2}{*}{2012} & Original value & 212.33 & 15.93 & .287 & .323 & .296 \\
\cline { 2 - 6 } & Projected value & 212.33 & 15.72 & .387 & .330 & .310 \\
& Adjusted rate & -- & $1.3 \%$ & $34.8 \%$ & $2.1 \%$ & $4.7 \%$ \\
\hline
\end{tabular}

Table 122012 Justin Verlander Slack Variable Analysis

\begin{tabular}{llccccc}
\hline & Technical Efficiency & IP & P/IP & $1 /$ ERA & $1 /$ FIP & 1/SIERA \\
\hline \multirow{2}{*}{2012} & Original value & 238.33 & 15.81 & .379 & .340 & .300 \\
\cline { 2 - 6 } & Projected value & 226.79 & 15.16 & .384 & .345 & .304 \\
& Adjusted rate & $-4.8 \%$ & $-4.1 \%$ & $1.3 \%$ & $1.4 \%$ & $1.3 \%$ \\
\hline
\end{tabular}

\section{Slack Variable Analysis of TE in sort " $G$ " in the VRS Model}

In the VRS model, the sort G means TE values lower than .90, as shown in Tables 13 and 14. We still used Grienke and Verlander as examples, but this time Grienke in 2010 and Verlander in 2013. In 2010, Grienke needed to hold his IP steady and lower his $\mathrm{P} / \mathrm{IP}$ to 14.07 as well as raise his $1 /$ ERA to $.333,1 / \mathrm{FIP}$ to .377 , and 1/SIERA to .329 for his TE value to equal 1. In 2013, Verlander needed to lower his IP to 211.42 and 
$\mathrm{P} / \mathrm{IP}$ to 15.31 as well as raise his $1 /$ ERA to $.378,1 / \mathrm{FIP}$ to .381 , and $1 /$ SIERA to .355 to achieve a TE of 1.

Table 132010 Zack Grienke Slack Variable Analysis

\begin{tabular}{ccccccc}
\hline & Technical Efficiency & IP & P/IP & 1/ERA & 1/FIP & 1/SIERA \\
\hline \multirow{3}{*}{2010} & Original value & 220.00 & 15.66 & .240 & .299 & .274 \\
& Projected value & 220.00 & 14.07 & .333 & .377 & .329 \\
& Adjusted rate & -- & $-10.2 \%$ & $38.8 \%$ & $26.1 \%$ & 20.1 \\
\hline
\end{tabular}

Table 142013 Justin Verlander Slack Variable Analysis

\begin{tabular}{ccccccc}
\hline & Technical Efficiency & IP & P/IP & 1/ERA & 1/FIP & 1/SIERA \\
\hline \multirow{2}{*}{2013} & Original value & 218.33 & 16.91 & .289 & .305 & .277 \\
& Projected value & 211.42 & 15.31 & .378 & .381 & .355 \\
& Adjusted rate & $-3.2 \%$ & $-9.4 \%$ & $30.8 \%$ & $24.9 \%$ & $28.2 \%$ \\
\hline
\end{tabular}

\section{Sensitivity Analysis in The VRS Model}

Sensitivity analysis is the study of how the output uncertainty of a mathematical model or system (numerical or otherwise) can be apportioned to different sources of input uncertainty. A related practice is uncertainty analysis, which has a greater focus on uncertainty quantification and propagation of uncertainty. Ideally, uncertainty and sensitivity analyses should be run in tandem.

As Table 15 shows, the result of the sensitivity analysis in the 2014 season demonstrated that 1/ERA was the biggest factor influencing the TE value. In other words, the average TE value of all DMUs in 2014 was .874. Without the 1/ERA event, the TE value would be lowered to .853 at a change rate of $-2.4 \%$.

\section{DISCUSSION AND CONCLUSIONS}

In this paper, we used the DEA technique to analyze the MLB starting pitchers' performances from 2008 to 2014. According to the analysis results, several players needed to adjust their performances.

In each single year, the IP and P/IP were not the highest for each of the pitchers who achieved the OE goal. For example, in 2013, Clayton Kershaw, Cliff Lee, and Felix Hernandez all achieved the goal, but their IP or P/IP were not the highest in the 2013 season; we found the same result in each season examined. This means a high IP 
or $\mathrm{P} / \mathrm{IP}$ is not the most important factor affecting the pitcher's performance. Liao and Chang (2013) showed that more pitches can affect a pitcher's performance indexes, such as FIP and ERA. It is important that starting pitchers and coaches focus on controlling their IP and P/IP.

Table 15 Sensitivity Analysis in the VRS Model in 2014

\begin{tabular}{ccl}
\hline $\begin{array}{c}\text { The Sequentially } \\
\text { Excluding Event }\end{array}$ & $\begin{array}{c}\text { Technical Efficiency } \\
\text { Averaged Changed Rate }\end{array}$ & \multicolumn{1}{c}{ Status } \\
\hline 1/ERA & $-2.4 \%$ & $\begin{array}{l}\text { Will change half of pitchers' TE } \\
\text { values. The biggest change is } \\
16.6 \% \text { for Johnny Cueto. }\end{array}$ \\
& $-1.9 \%$ & $\begin{array}{l}\text { Will change more than half of } \\
\text { pitchers' TE values. The biggest } \\
\text { change is }-12.2 \% \text { for Jon Lester. }\end{array}$ \\
\hline 1/FIP & & $\begin{array}{l}\text { Will change more than half of } \\
\text { pitchers' TE values. The biggest } \\
\text { change is }-10.2 \% \text { for Stephen } \\
\text { 1/SIERA }\end{array}$ \\
& $-1.9 \%$ & Strasburg. \\
\hline
\end{tabular}

Second, we demonstrated a sort of technical efficiency in Table 10, which showed that many of the DMUs we collected needed to fix their performance to reach the overall efficiency to 1 . Using Grienke and Verlander as examples, Grienke won the Cy Lee, Shih, \& Huang Award in 2008, when his OE was 1; however, he dropped in the 2010 season. The slack variable analysis indicated that he needed a significant change to adjust his 1/ERA, 1/FIP, and 1/SIERA, as he did in 2012 and 2014. The results might conform to his speech in 2008, indicating that he knew to use these advanced statistics to adjust his performance. Meanwhile, Verlander's performance based on the analysis results showed that he dropped further and further after he won the American League Cy Lee, Shih, \& Huang Award in 2011; this might be related to his IP and P/IP, as previously mentioned.

Tango (2008) pointed out that the number of HRs might be affected by the location of the game, because each of the stadiums for the 30 MLB teams is different and unique. Thus, SIERA can provide more details for FBs and GBs, but the shortcoming is that it is too complex to calculate. Although both FIP and SIERA are characterized by some shortcomings, both can predict the ERA trends. Therefore, we can effectively use these 
statistics to train or choose a pitcher, rather than just follow the ERA. Actually, FIP does a better job of predicting the future than measuring the present, as small samples could show considerable fluctuations. It is less effective in describing a pitcher's single-game performance and is more appropriate for a season's innings.

Finally, Chen (2006) pointed out that ERA $<$ FIP, implying that the team is playing a good defensive game. In other words, the FIP can not only benefit the baseball pitcher, but also identify the team's deficiency in defense, which can then be addressed.

The baseball team manager can use these results to choose pitchers and justify the team's salary cap, for example. The team sponsors can also refer to them to make decisions about sponsorship relationships. Likewise the coach can prepare training schedules and control the IP and P/IP appropriately based on the results. Pitchers can rate themselves in comparison to excellent pitchers and set clear targets to avoid inefficient training and unnecessary injuries.

\section{REFERENCES}

Bradbury, J. C. (2007). Does the baseball labor market properly value pitchers. Journal of Sports Economics, 8(6), 616-632. http://dx.doi.org/10.1177/1527002506296366

Charnes, A., Cooper, W. W., \& Rhodes, E. (1978). Measuring the efficiency of decision making units. European Journal of Operational Research, 2(6), 429-444. http://dx.doi.org/10.1016/0377-2217(78)90138-8

Charnes, A., Cooper, W. W., \& Thrall, R. M. (1991). A structure for classifying and characterizing efficiencies and inefficiencies in data envelopment analysis. The Journal of Productivity Analysis, 2(3), 179-237. http://dx.doi.org/10.1007/BF00159732

Chen, C.,C. (2006). Analysis of the performance of foreign players before and after coming to Chinese Professional Baseball League (Unpublished master dissertation). National Taiwan University of Sport, Taichung, Taiwan.

Chen, W. C., \& Johnson, A. L. (2010). Thedynamics of performance space of MajorLeague Baseball pitchers 1871-2006. Annalsof Operations Research, 181(1), 287-302. http://dx.doi.org/10.1007/s10479-010-0743-9

Cooper, W. W., Seiford, L. M., \& Tone, K. (1999). Data envelopment analysis: A comprehensive text with models, applications, references and DEA-solver software. Boston: Kluwer Academic Publishers.

Golany, B., \& Roll, Y. (1989). An application procedure for DEA. OMEGA, 17(3), 237-250. http://dx.doi.org/10.1016/0305-0483(89)90029-7 
Howard, L. W., \& Miller, J. L. (1993). Fair pay for fair play: Estimating pay equityin professional baseball with data envelopment analysis. Academy ofManagement Journal, 36(4), 882-894. http://dx.doi.org/10.2307/256763

Kao, L. S. (2011). A Study of Investigating Attributes Attracting the Audience in the Activity of Watching Sports. Leisure Industry Research, 9(2), 39-56.

Kenper, T. (2009, November 17). Use of Statics Helps Greinke to C.Y. Award. The New York Times.

Keri, J. (2011) The extra 2\%: How wall street strategies took a major league baseball team from worst to first. CT: ESPN Books.

Kindall, J. (1993). Sports illustrated baseball: Play the winning way. Lanham, MD: Time, Inc.

Leibenstein, H., \& Maital, S. (1992). Empirical estimation and partitioning of X-inefficiency: A data envelopment approach. The American Economic Review, 82(2), 428-433. http://www.jstor.org/stable/2117439

Lee, Y. L., Shih, C. P., \& Huang, H. C. (2011). An analysis of team performance in major league baseball. Journal of Taiwan Society for Sport Management, 11(4), 317-335.

Lewis, M. (2004). Moneyball: The ate of winning an unfair game. NY. W. W. Norton \& Company, Inc.

Lewis, H. F., Lock, K. A., \& Sexton, T. R. (2009). Orgnizational efficiency, and competitiveness in Major League Baseball. Journal of Sports Economics, 8(3), 266-294.

Lin, W. B. (2004). Measuring Pitchers' Performance Using Data Envelopment Analysis. Sports \& Exercise Research, 6(3), 119-131.

Lin, W. B. (2010). A nation's performance management for international mega sport events-evidences from the east Asian games. Physical Education Journal, 43(4), 109-126

Liao, P. Y., Chang, C. K. (2013). The Effect of Pitch Count on Subsequent Performance in Major League Baseball Starting Pitchers. Journal of Physical Activity and Exercise Science. 2(2), 13-25.

Lopez, A., \& Kirkgard, J. (1996). Coaching baseball successfully. Champaign, IL: Human Kinetics.

MLB.com (2015). Awards. Retrieved August 26, 2015, from http://m.mlb.com/awards/?year=2008

Norman, M., \& Stocker, B. (1991). Data envelopment analysis: The assessment of performance. Chichester UK: John Wiley and Sons. 
Piette, J., Braunstein, A., McShane, B. B., \& Jensen, S. T. (2010). A point-mass mixture random effects model for pitching metrics. Journal of Quantitative Analysis in Sports, 6(3), 8. http://dx.doi.org/10.2202/1559-0410.1237

Sexton, T. R., \& Lewis, H. F. (2003). Two stage DEA: An application to major league baseball. Journal of Productivity Analysis, 19(2-3), 227-249. http://dx.doi.org/10.1023/A:1022861618317

Sun, S. (2004). Data Envelopment Analysi-Theory and Applications. Taipei, Yang-Chih Book Co., Ltd.

Tengo, T. (2008). Changes in home run rates during the Retrosheet years. Retrieved December 20, 2014, from http://www.hardballtimes.com/changes-in-home-run-rates-during-the-retrosheetyears/

Tsai, C. H., \& Chao, F. M. (2009). Performance Evaluation for WTA Players-An Application of DEA. Sports \& Exercise Research, 11(1), 29-41.

Yeh, C. S., Lee, M. S., \& Zhu, F. L. (2003). Baseball Bible. Taipei, Business Weekly Publication, Inc. 
APPENDIX

Stats of MLB 2008 Season's Starting Pitchers

\begin{tabular}{|c|c|c|c|c|c|}
\hline DMUs & IP & $\mathrm{P} / \mathrm{IP}$ & 1/ERA & 1/FIP & 1/SIERA \\
\hline Tim Lincecum & 223.00 & 16.13 & 0.382 & 0.386 & 0.319 \\
\hline Cliff Lee & 223.33 & 14.73 & 0.394 & 0.353 & 0.278 \\
\hline CC Sabathia & 253.00 & 15.08 & 0.370 & 0.344 & 0.317 \\
\hline Dan Haren & 216.00 & 15.46 & 0.300 & 0.332 & 0.313 \\
\hline Roy Halladay & 243.67 & 14.52 & 0.356 & 0.328 & 0.318 \\
\hline Derek Lowe & 211.00 & 14.87 & 0.309 & 0.307 & 0.297 \\
\hline Brandon Webb & 226.67 & 14.82 & 0.303 & 0.305 & 0.310 \\
\hline Ervin Santana & 219.00 & 15.65 & 0.287 & 0.303 & 0.301 \\
\hline Mike Mussina & 200.33 & 15.65 & 0.297 & 0.301 & 0.282 \\
\hline Ryan Dempster & 206.67 & 16.17 & 0.338 & 0.293 & 0.263 \\
\hline A.J. Burnett & 220.33 & 16.46 & 0.250 & 0.290 & 0.280 \\
\hline Johan Santana & 234.33 & 15.35 & 0.395 & 0.285 & 0.271 \\
\hline Zack Greinke & 202.33 & 15.95 & 0.288 & 0.281 & 0.271 \\
\hline Gil Meche & 210.33 & 16.90 & 0.251 & 0.277 & 0.249 \\
\hline Jon Lester & 210.33 & 15.73 & 0.312 & 0.275 & 0.241 \\
\hline Andy Pettitte & 204.00 & 16.05 & 0.220 & 0.270 & 0.263 \\
\hline Cole Hamels & 227.33 & 15.08 & 0.324 & 0.269 & 0.275 \\
\hline Javier Vazquez & 208.33 & 16.21 & 0.214 & 0.267 & 0.273 \\
\hline Aaron Cook & 211.33 & 14.54 & 0.253 & 0.266 & 0.236 \\
\hline Ricky Nolasco & 206.67 & 15.39 & 0.277 & 0.264 & 0.283 \\
\hline Felix Hernandez & 200.67 & 15.94 & 0.290 & 0.263 & 0.254 \\
\hline Roy Oswalt & 208.67 & 14.83 & 0.282 & 0.263 & 0.278 \\
\hline James Shields & 215.00 & 14.56 & 0.281 & 0.262 & 0.263 \\
\hline Matt Cain & 217.67 & 16.57 & 0.266 & 0.256 & 0.229 \\
\hline Mark Buehrle & 218.67 & 15.50 & 0.264 & 0.254 & 0.243 \\
\hline Mike Pelfrey & 200.67 & 16.56 & 0.269 & 0.253 & 0.217 \\
\hline Paul Maholm & 206.33 & 14.74 & 0.270 & 0.241 & 0.246 \\
\hline Justin Verlander & 201.00 & 17.55 & 0.207 & 0.239 & 0.223 \\
\hline Ted Lilly & 204.67 & 15.83 & 0.244 & 0.227 & 0.255 \\
\hline Gavin Floyd & 206.33 & 15.68 & 0.260 & 0.210 & 0.223 \\
\hline Scott Olsen & 201.67 & 15.41 & 0.238 & 0.199 & 0.200 \\
\hline
\end{tabular}


2008 Overview of DMUs

\begin{tabular}{|c|c|c|c|}
\hline DMUs & $\begin{array}{l}\text { Overall } \\
\text { Efficiency }\end{array}$ & $\begin{array}{l}\text { Scale } \\
\text { Efficiency }\end{array}$ & $\begin{array}{l}\text { Technical } \\
\text { Efficiency }\end{array}$ \\
\hline Tim Lincecum & 1 & 1 & 1 \\
\hline Cliff Lee & 1 & 1 & 1 \\
\hline CC Sabathia & 0.993 & 1 & 0.993 \\
\hline Dan Haren & 1 & 1 & 1 \\
\hline Roy Halladay & 1 & 1 & 1 \\
\hline Derek Lowe & 0.986 & 1 & 0.986 \\
\hline Brandon Webb & 0.995 & 1 & 0.995 \\
\hline Ervin Santana & 0.949 & 0.955 & 0.994 \\
\hline Mike Mussina & 0.976 & 1 & 0.976 \\
\hline Ryan Dempster & 0.943 & 1 & 0.943 \\
\hline A.J. Burnett & 0.877 & 0.884 & 0.992 \\
\hline Johan Santana & 0.962 & 1 & 0.962 \\
\hline Zack Greinke & 0.930 & 0.950 & 0.979 \\
\hline Gil Meche & 0.821 & 0.832 & 0.987 \\
\hline Jon Lester & 0.854 & 0.896 & 0.952 \\
\hline Andy Pettitte & 0.890 & 0.909 & 0.979 \\
\hline Cole Hamels & 0.887 & 0.898 & 0.988 \\
\hline Javier Vazquez & 0.904 & 0.917 & 0.987 \\
\hline Aaron Cook & 0.796 & 1 & 0.796 \\
\hline Ricky Nolasco & 0.946 & 0.967 & 0.979 \\
\hline Felix Hernandez & 0.882 & 0.969 & 0.910 \\
\hline Roy Oswalt & 0.927 & 1 & 0.927 \\
\hline James Shields & 0.876 & 1 & 0.876 \\
\hline Matt Cain & 0.734 & 0.738 & 0.995 \\
\hline Mark Buehrle & 0.778 & 0.782 & 0.996 \\
\hline Mike Pelfrey & 0.778 & 0.899 & 0.865 \\
\hline Paul Maholm & 0.833 & 1 & 0.833 \\
\hline Justin Verlander & 0.766 & 0.788 & 0.973 \\
\hline Ted Lilly & 0.860 & 0.878 & 0.980 \\
\hline Gavin Floyd & 0.754 & 0.799 & 0.943 \\
\hline Scott Olsen & 0.693 & 1 & 0.693 \\
\hline
\end{tabular}


Stats of MLB 2009 Season's Starting Pitchers

\begin{tabular}{|c|c|c|c|c|c|}
\hline DMUs & IP & $\mathrm{P} / \mathrm{IP}$ & 1/ERA & 1/FIP & 1/SIERA \\
\hline Zack Greinke & 229.33 & 15.16 & 0.463 & 0.429 & 0.329 \\
\hline Tim Lincecum & 225.33 & 15.26 & 0.403 & 0.427 & 0.344 \\
\hline Javier Vazquez & 219.33 & 15.11 & 0.348 & 0.361 & 0.350 \\
\hline Justin Verlander & 240.00 & 16.40 & 0.290 & 0.357 & 0.327 \\
\hline Roy Halladay & 239.00 & 14.20 & 0.358 & 0.327 & 0.321 \\
\hline Josh Johnson & 209.00 & 15.71 & 0.310 & 0.327 & 0.290 \\
\hline Felix Hernandez & 238.67 & 15.22 & 0.402 & 0.324 & 0.291 \\
\hline $\begin{array}{l}\text { Adam } \\
\text { Wainwright }\end{array}$ & 233.00 & 15.51 & 0.380 & 0.322 & 0.288 \\
\hline Cliff Lee & 231.67 & 15.25 & 0.311 & 0.322 & 0.265 \\
\hline Jon Lester & 203.33 & 16.74 & 0.293 & 0.317 & 0.317 \\
\hline Dan Haren & 229.33 & 15.09 & 0.318 & 0.310 & 0.327 \\
\hline Joel Pineiro & 214.00 & 13.80 & 0.287 & 0.306 & 0.275 \\
\hline Ubaldo Jimenez & 218.00 & 16.38 & 0.288 & 0.298 & 0.266 \\
\hline CC Sabathia & 230.00 & 15.60 & 0.297 & 0.295 & 0.264 \\
\hline Wandy Rodriguez & 205.67 & 16.37 & 0.331 & 0.282 & 0.278 \\
\hline Josh Beckett & 212.33 & 15.86 & 0.259 & 0.275 & 0.294 \\
\hline Jair Jurrjens & 215.00 & 15.37 & 0.385 & 0.272 & 0.226 \\
\hline Ryan Dempster & 200.00 & 15.80 & 0.274 & 0.258 & 0.260 \\
\hline Matt Cain & 217.67 & 15.45 & 0.346 & 0.257 & 0.239 \\
\hline Randy Wolf & 214.33 & 15.33 & 0.310 & 0.253 & 0.244 \\
\hline James Shields & 219.67 & 15.15 & 0.242 & 0.249 & 0.251 \\
\hline Jered Weaver & 211.00 & 16.12 & 0.267 & 0.248 & 0.235 \\
\hline Jason Marquis & 216.00 & 15.03 & 0.248 & 0.244 & 0.217 \\
\hline Matt Garza & 203.00 & 16.85 & 0.253 & 0.240 & 0.251 \\
\hline Zach Duke & 213.00 & 14.42 & 0.246 & 0.236 & 0.219 \\
\hline Edwin Jackson & 214.00 & 16.20 & 0.276 & 0.234 & 0.233 \\
\hline A.J. Burnett & 207.00 & 16.72 & 0.248 & 0.231 & 0.239 \\
\hline Nick Blackburn & 205.67 & 15.08 & 0.248 & 0.229 & 0.214 \\
\hline Mark Buehrle & 213.33 & 15.06 & 0.260 & 0.224 & 0.216 \\
\hline Jon Garland & 204.00 & 15.96 & 0.249 & 0.223 & 0.210 \\
\hline John Danks & 200.33 & 16.02 & 0.265 & 0.218 & 0.228 \\
\hline John Lannan & 206.33 & 15.12 & 0.258 & 0.213 & 0.203 \\
\hline Bronson Arroyo & 220.33 & 15.46 & 0.260 & 0.209 & 0.216 \\
\hline Doug Davis & 203.33 & 17.07 & 0.243 & 0.207 & 0.204 \\
\hline Jeremy Guthrie & 200.00 & 16.80 & 0.198 & 0.188 & 0.198 \\
\hline
\end{tabular}


2009 Overview of DMUs

\begin{tabular}{|c|c|c|c|}
\hline DMUs & Overall Efficiency & Scale Efficiency & Technical Efficiency \\
\hline Zack Greinke & 1 & 1 & 1 \\
\hline Tim Lincecum & 1 & 1 & 1 \\
\hline Javier Vazquez & 1 & 1 & 1 \\
\hline Justin Verlander & 0.868 & 0.939 & 0.924 \\
\hline Roy Halladay & 0.994 & 1 & 0.994 \\
\hline Josh Johnson & 0.888 & 1 & 0.888 \\
\hline Felix Hernandez & 0.877 & 0.880 & 0.997 \\
\hline Adam Wainwright & 0.844 & 0.861 & 0.980 \\
\hline Cliff Lee & 0.771 & 0.771 & 1 \\
\hline Jon Lester & 0.977 & 1 & 0.977 \\
\hline Dan Haren & 0.936 & 0.936 & 1 \\
\hline Joel Pineiro & 0.869 & 1 & 0.869 \\
\hline Ubaldo Jimenez & 0.782 & 0.791 & 0.989 \\
\hline CC Sabathia & 0.745 & 0.764 & 0.976 \\
\hline Wandy Rodriguez & 0.890 & 1 & 0.890 \\
\hline Josh Beckett & 0.868 & 0.876 & 0.990 \\
\hline Jair Jurrjens & 0.887 & 1 & 0.887 \\
\hline Ryan Dempster & 0.827 & 1 & 0.827 \\
\hline Matt Cain & 0.787 & 0.874 & 0.901 \\
\hline Randy Wolf & 0.766 & 0.858 & 0.893 \\
\hline James Shields & 0.716 & 0.717 & 0.998 \\
\hline Jered Weaver & 0.723 & 0.766 & 0.944 \\
\hline Jason Marquis & 0.653 & 0.712 & 0.917 \\
\hline Matt Garza & 0.778 & 0.853 & 0.911 \\
\hline Zach Duke & 0.669 & 0.796 & 0.840 \\
\hline Edwin Jackson & 0.716 & 0.748 & 0.956 \\
\hline A.J. Burnett & 0.732 & 0.771 & 0.949 \\
\hline Nick Blackburn & 0.679 & 0.872 & 0.779 \\
\hline Mark Buehrle & 0.669 & 0.764 & 0.876 \\
\hline Jon Garland & 0.677 & 0.809 & 0.836 \\
\hline John Danks & 0.744 & 0.956 & 0.778 \\
\hline John Lannan & 0.662 & 0.882 & 0.751 \\
\hline Bronson Arroyo & 0.648 & 0.662 & 0.979 \\
\hline Doug Davis & 0.661 & 0.790 & 0.836 \\
\hline Jeremy Guthrie & 0.621 & 0.762 & 0.816 \\
\hline
\end{tabular}


Stats of MLB 2010 Season's Starting Pitchers (a)

\begin{tabular}{|c|c|c|c|c|c|}
\hline DMUs & IP & $\mathrm{P} / \mathrm{IP}$ & 1/ERA & 1/FIP & 1/SIERA \\
\hline Cliff Lee & 212.33 & 14.03 & 0.314 & 0.388 & 0.325 \\
\hline Adam Wainwright & 230.33 & 14.57 & 0.413 & 0.350 & 0.322 \\
\hline Justin Verlander & 224.33 & 16.70 & 0.297 & 0.337 & 0.289 \\
\hline Roy Halladay & 250.67 & 14.23 & 0.410 & 0.332 & 0.347 \\
\hline Felix Hernandez & 249.67 & 14.94 & 0.441 & 0.329 & 0.314 \\
\hline Jered Weaver & 224.33 & 16.55 & 0.332 & 0.327 & 0.319 \\
\hline Ubaldo Jimenez & 221.67 & 16.24 & 0.347 & 0.323 & 0.273 \\
\hline Clayton Kershaw & 204.33 & 16.59 & 0.344 & 0.321 & 0.282 \\
\hline Jon Lester & 208.00 & 16.14 & 0.308 & 0.319 & 0.310 \\
\hline Tim Lincecum & 212.33 & 16.19 & 0.292 & 0.317 & 0.313 \\
\hline Roy Oswalt & 210.67 & 15.08 & 0.366 & 0.305 & 0.299 \\
\hline Tommy Hanson & 202.66 & 16.15 & 0.300 & 0.302 & 0.269 \\
\hline Zack Greinke & 220.00 & 15.66 & 0.240 & 0.299 & 0.274 \\
\hline David Price & 207.67 & 16.09 & 0.366 & 0.292 & 0.260 \\
\hline CC Sabathia & 237.67 & 15.09 & 0.314 & 0.282 & 0.272 \\
\hline Colby Lewis & 201.00 & 16.42 & 0.269 & 0.282 & 0.281 \\
\hline Brett Myers & 223.67 & 15.46 & 0.318 & 0.281 & 0.265 \\
\hline C.J. Wilson & 204.00 & 16.87 & 0.299 & 0.281 & 0.240 \\
\hline Ricky Romero & 210.00 & 15.43 & 0.268 & 0.275 & 0.265 \\
\hline Matt Cain & 223.33 & 15.68 & 0.318 & 0.274 & 0.255 \\
\hline Cole Hamels & 208.67 & 16.14 & 0.327 & 0.272 & 0.309 \\
\hline Chris Carpenter & 235.00 & 15.10 & 0.311 & 0.271 & 0.270 \\
\hline John Danks & 213.00 & 15.91 & 0.269 & 0.270 & 0.246 \\
\hline Dan Haren & 235.00 & 15.95 & 0.256 & 0.270 & 0.291 \\
\hline Gio Gonzalez & 200.67 & 16.79 & 0.310 & 0.265 & 0.240 \\
\hline Mike Pelfrey & 203.00 & 16.69 & 0.272 & 0.262 & 0.218 \\
\hline Clayton Richard & 201.67 & 15.93 & 0.267 & 0.262 & 0.237 \\
\hline John Lackey & 215.00 & 16.74 & 0.227 & 0.260 & 0.238 \\
\hline Edwin Jackson & 209.33 & 16.04 & 0.224 & 0.259 & 0.261 \\
\hline Mark Buehrle & 210.33 & 15.72 & 0.234 & 0.256 & 0.213 \\
\hline Livan Hernandez & 211.67 & 15.34 & 0.273 & 0.253 & 0.210 \\
\hline Ryan Dempster & 215.33 & 16.70 & 0.260 & 0.251 & 0.270 \\
\hline Carl Pavano & 221.00 & 14.20 & 0.267 & 0.249 & 0.248 \\
\hline Tim Hudson & 228.67 & 14.60 & 0.353 & 0.244 & 0.269 \\
\hline Roberto Hernandez & 210.33 & 15.71 & 0.265 & 0.243 & 0.232 \\
\hline
\end{tabular}


Stats of MLB 2010 Season's Starting Pitchers (b)

\begin{tabular}{llrrrr}
\hline \multicolumn{1}{c}{ DMUs } & IP & P/IP & 1/ERA & 1/FIP & \multicolumn{1}{c}{ 1/SIERA } \\
\hline Jake Westbrook & 202.67 & 16.45 & 0.237 & 0.237 & 0.247 \\
James Shields & 202.33 & 16.50 & 0.192 & 0.236 & 0.283 \\
Ervin Santana & 222.67 & 15.99 & 0.255 & 0.234 & 0.236 \\
Jon Garland & 200.00 & 16.27 & 0.288 & 0.227 & 0.225 \\
Matt Garza & 204.00 & 15.99 & 0.254 & 0.227 & 0.236 \\
Jeremy Guthrie & 209.33 & 15.89 & 0.261 & 0.225 & 0.223 \\
Joe Saunders & 203.33 & 16.30 & 0.224 & 0.219 & 0.214 \\
Bronson Arroyo & 215.67 & 15.10 & 0.258 & 0.217 & 0.220 \\
Randy Wolf & 215.67 & 16.58 & 0.240 & 0.206 & 0.212 \\
Rodrigo Lopez & 200.00 & 15.44 & 0.200 & 0.192 & 0.215 \\
\hline
\end{tabular}


2010 Overview of DMUs (a)

\begin{tabular}{|c|c|c|c|}
\hline DMUs & $\begin{array}{l}\text { Overall } \\
\text { Efficiency }\end{array}$ & $\begin{array}{l}\text { Scale } \\
\text { Efficiency }\end{array}$ & $\begin{array}{l}\text { Technical } \\
\text { Efficiency }\end{array}$ \\
\hline Cliff Lee & 1 & 1 & 1 \\
\hline Adam Wainwright & 1 & 1 & 1 \\
\hline Justin Verlander & 0.857 & 0.888 & 0.965 \\
\hline Roy Halladay & 1 & 1 & 1 \\
\hline Felix Hernandez & 1 & 1 & 1 \\
\hline Jered Weaver & 0.950 & 0.962 & 0.987 \\
\hline Ubaldo Jimenez & 0.913 & 0.916 & 0.997 \\
\hline Clayton Kershaw & 0.983 & 1 & 0.983 \\
\hline Jon Lester & 0.982 & 1 & 0.982 \\
\hline Tim Lincecum & 0.963 & 0.963 & 1 \\
\hline Roy Oswalt & 0.999 & 1 & 0.999 \\
\hline Tommy Hanson & 0.906 & 1 & 0.906 \\
\hline Zack Greinke & 0.814 & 0.832 & 0.978 \\
\hline David Price & 0.923 & 1 & 0.983 \\
\hline CC Sabathia & 0.793 & 0.808 & 0.981 \\
\hline Colby Lewis & 0.913 & 1 & 0.913 \\
\hline Brett Myers & 0.828 & 0.828 & 1 \\
\hline C.J. Wilson & 0.859 & 0.887 & 0.969 \\
\hline Ricky Romero & 0.836 & 0.840 & 0.994 \\
\hline Matt Cain & 0.809 & 0.809 & 1 \\
\hline Cole Hamels & 0.994 & 1 & 0.994 \\
\hline Chris Carpenter & 0.793 & 0.807 & 0.982 \\
\hline John Danks & 0.783 & 0.784 & 1 \\
\hline Dan Haren & 0.809 & 0.861 & 0.940 \\
\hline Gio Gonzalez & 0.865 & 1 & 0.865 \\
\hline Mike Pelfrey & 0.795 & 0.860 & 0.924 \\
\hline Clayton Richard & 0.805 & 0.997 & 0.807 \\
\hline John Lackey & 0.723 & 0.729 & 0.992 \\
\hline Edwin Jackson & 0.815 & 0.830 & 0.982 \\
\hline Mark Buehrle & 0.704 & 0.709 & 0.994 \\
\hline Livan Hernandez & 0.751 & 0.765 & 0.981 \\
\hline Ryan Dempster & 0.819 & 0.826 & 0.991 \\
\hline Carl Pavano & 0.760 & 0.761 & 0.999 \\
\hline Tim Hudson & 0.861 & 0.865 & 0.996 \\
\hline Roberto Hernandez & 0.759 & 0.761 & 0.997 \\
\hline
\end{tabular}


2010 Overview of DMUs (b)

\begin{tabular}{llll}
\hline DMUs & $\begin{array}{l}\text { Overall } \\
\text { Efficiency }\end{array}$ & $\begin{array}{l}\text { Scale } \\
\text { Efficiency }\end{array}$ & $\begin{array}{l}\text { Technical } \\
\text { Efficiency }\end{array}$ \\
\hline Jake Westbrook & 0.796 & 0.858 & 0.928 \\
James Shields & 0.914 & 0.988 & 0.925 \\
Ervin Santana & 0.716 & 0.721 & 0.994 \\
Jon Garland & 0.804 & 1 & 0.804 \\
Matt Garza & 0.781 & 0.837 & 0.933 \\
Jeremy Guthrie & 0.739 & 0.743 & 0.994 \\
Joe Saunders & 0.704 & 0.748 & 0.942 \\
Bronson Arroyo & 0.708 & 0.708 & 0.999 \\
Randy Wolf & 0.674 & 0.674 & 1 \\
Rodrigo Lopez & 0.702 & 1 & 0.702 \\
\hline
\end{tabular}


Stats of MLB 2011 Season's Starting Pitchers (a)

\begin{tabular}{|c|c|c|c|c|c|}
\hline DMUs & IP & $\mathrm{P} / \mathrm{IP}$ & 1/ERA & 1/FIP & 1/SIERA \\
\hline Roy Halladay & 233.67 & 14.84 & 0.426 & 0.455 & 0.360 \\
\hline Clayton Kershaw & 233.33 & 14.87 & 0.439 & 0.405 & 0.357 \\
\hline Cliff Lee & 232.67 & 14.63 & 0.417 & 0.385 & 0.369 \\
\hline $\begin{array}{l}\text { Madison } \\
\text { Bumgarner }\end{array}$ & 204.67 & 15.64 & 0.312 & 0.375 & 0.315 \\
\hline CC Sabathia & 237.33 & 15.19 & 0.333 & 0.347 & 0.319 \\
\hline Matt Cain & 221.67 & 15.74 & 0.347 & 0.344 & 0.265 \\
\hline Justin Verlander & 251.00 & 15.70 & 0.417 & 0.334 & 0.336 \\
\hline Dan Haren & 237.33 & 15.85 & 0.313 & 0.334 & 0.299 \\
\hline Cole Hamels & 213.00 & 14.52 & 0.364 & 0.333 & 0.331 \\
\hline Doug Fister & 213.33 & 14.79 & 0.348 & 0.330 & 0.273 \\
\hline Chris Carpenter & 237.33 & 15.22 & 0.290 & 0.327 & 0.287 \\
\hline Felix Hernandez & 233.67 & 15.44 & 0.288 & 0.319 & 0.312 \\
\hline Tim Lincecum & 217.00 & 16.62 & 0.365 & 0.315 & 0.290 \\
\hline Jered Weaver & 235.67 & 15.90 & 0.415 & 0.313 & 0.273 \\
\hline Ian Kennedy & 222.00 & 15.42 & 0.347 & 0.311 & 0.291 \\
\hline C.J. Wilson & 223.33 & 16.08 & 0.340 & 0.309 & 0.291 \\
\hline Justin Masterson & 215.00 & 16.00 & 0.311 & 0.305 & 0.272 \\
\hline Daniel Hudson & 222.00 & 15.48 & 0.287 & 0.305 & 0.265 \\
\hline David Price & 224.33 & 16.48 & 0.287 & 0.301 & 0.307 \\
\hline Tim Hudson & 215.00 & 14.90 & 0.311 & 0.295 & 0.292 \\
\hline James Shields & 249.33 & 14.34 & 0.355 & 0.292 & 0.305 \\
\hline Ricky Nolasco & 206.00 & 15.51 & 0.214 & 0.282 & 0.265 \\
\hline Yovani Gallardo & 207.33 & 16.70 & 0.284 & 0.279 & 0.312 \\
\hline Gio Gonzalez & 202.00 & 16.87 & 0.321 & 0.275 & 0.265 \\
\hline Shaun Marcum & 200.67 & 15.85 & 0.282 & 0.268 & 0.256 \\
\hline Hiroki Kuroda & 202.00 & 15.85 & 0.326 & 0.265 & 0.274 \\
\hline R.A. Dickey & 207.67 & 15.00 & 0.304 & 0.265 & 0.249 \\
\hline Ryan Dempster & 202.33 & 17.37 & 0.208 & 0.256 & 0.265 \\
\hline Mark Buehrle & 205.33 & 15.32 & 0.279 & 0.251 & 0.229 \\
\hline Ervin Santana & 228.67 & 15.10 & 0.296 & 0.250 & 0.254 \\
\hline Jason Vargas & 201.00 & 16.17 & 0.235 & 0.244 & 0.226 \\
\hline Trevor Cahill & 207.67 & 16.30 & 0.240 & 0.244 & 0.249 \\
\hline Carl Pavano & 222.00 & 15.24 & 0.233 & 0.244 & 0.233 \\
\hline Ricky Romero & 225.00 & 15.00 & 0.342 & 0.238 & 0.265 \\
\hline Brett Myers & 214.00 & 15.49 & 0.224 & 0.236 & 0.260 \\
\hline
\end{tabular}


Stats of MLB 2011 Season's Starting Pitchers (b)

\begin{tabular}{lllccc}
\hline \multicolumn{1}{c}{ DMUs } & IP & P/IP & 1/ERA & 1/FIP & 1/SIERA \\
\hline Randy Wolf & 212.33 & 15.90 & 0.271 & 0.233 & 0.223 \\
Jeremy Guthrie & 203.67 & 15.89 & 0.229 & 0.222 & 0.222 \\
Colby Lewis & 200.33 & 16.01 & 0.227 & 0.220 & 0.258 \\
Joe Saunders & 212.00 & 15.17 & 0.271 & 0.209 & 0.213 \\
\hline
\end{tabular}


2011 Overview of DMUs (a)

\begin{tabular}{|c|c|c|c|}
\hline DMUs & Overall Efficiency & Scale Efficiency & Technical Efficiency \\
\hline Roy Halladay & 1 & 1 & 1 \\
\hline Clayton Kershaw & 1 & 1 & 1 \\
\hline Cliff Lee & 1 & 1 & 1 \\
\hline Madison Bumgarner & 0.989 & 1 & 0.989 \\
\hline CC Sabathia & 0.853 & 0.869 & 0.981 \\
\hline Matt Cain & 0.845 & 0.891 & 0.948 \\
\hline Justin Verlander & 0.900 & 0.950 & 0.947 \\
\hline Dan Haren & 0.802 & 0.817 & 0.982 \\
\hline Cole Hamels & 0.980 & 1 & 0.980 \\
\hline Doug Fister & 0.812 & 0.960 & 0.908 \\
\hline Chris Carpenter & 0.772 & 0.786 & 0.982 \\
\hline Felix Hernandez & 0.842 & 0.846 & 0.996 \\
\hline Tim Lincecum & 0.894 & 0.960 & 0.931 \\
\hline Jered Weaver & 0.936 & 0.945 & 0.990 \\
\hline Ian Kennedy & 0.845 & 0.872 & 0.969 \\
\hline C.J. Wilson & 0.833 & 0.846 & 0.985 \\
\hline Justin Masterson & 0.806 & 0.850 & 0.948 \\
\hline Daniel Hudson & 0.763 & 0.766 & 0.996 \\
\hline David Price & 0.863 & 0.870 & 0.992 \\
\hline Tim Hudson & 0.856 & 0.872 & 0.982 \\
\hline James Shields & 0.858 & 1 & 0.858 \\
\hline Ricky Nolasco & 0.813 & 0.834 & 0.975 \\
\hline Yovani Gallardo & 0.949 & 0.975 & 0.974 \\
\hline Gio Gonzalez & 0.852 & 1 & 0.852 \\
\hline Shaun Marcum & 0.805 & 1 & 0.805 \\
\hline Hiroki Kuroda & 0.874 & 1 & 0.874 \\
\hline R.A. Dickey & 0.781 & 1 & 0.781 \\
\hline Ryan Dempster & 0.826 & 0.932 & 0.886 \\
\hline Mark Buehrle & 0.726 & 0.912 & 0.796 \\
\hline Ervin Santana & 0.709 & 0.714 & 0.994 \\
\hline Jason Vargas & 0.712 & 0.881 & 0.808 \\
\hline Trevor Cahill & 0.756 & 0.776 & 0.974 \\
\hline Carl Pavano & 0.662 & 0.669 & 0.990 \\
\hline Ricky Romero & 0.808 & 0.837 & 0.966 \\
\hline Brett Myers & 0.766 & 0.781 & 0.981 \\
\hline
\end{tabular}


2011 Overview of DMUs (b)

\begin{tabular}{llll}
\hline \multicolumn{1}{c}{ DMUs } & Overall & Scale & Technical \\
& Efficiency & Efficiency & Efficiency \\
\hline Randy Wolf & 0.683 & 0.746 & 0.915 \\
Jeremy Guthrie & 0.687 & 0.739 & 0.930 \\
Colby Lewis & 0.812 & 1 & 0.812 \\
Joe Saunders & 0.679 & 0.750 & 0.906 \\
\hline
\end{tabular}


Stats of MLB 2012 Season's Starting Pitchers

\begin{tabular}{|c|c|c|c|c|c|}
\hline DMUs & IP & $\mathrm{P} / \mathrm{IP}$ & 1/ERA & 1/FIP & 1/SIERA \\
\hline Felix Hernandez & 232.00 & 14.74 & 0.327 & 0.352 & 0.305 \\
\hline Clayton Kershaw & 227.67 & 15.24 & 0.395 & 0.346 & 0.302 \\
\hline Justin Verlander & 238.33 & 15.81 & 0.379 & 0.340 & 0.300 \\
\hline David Price & 211.00 & 15.79 & 0.391 & 0.328 & 0.310 \\
\hline Zack Greinke & 212.33 & 15.93 & 0.287 & 0.323 & 0.296 \\
\hline Cliff Lee & 211.00 & 14.69 & 0.316 & 0.319 & 0.326 \\
\hline R.A. Dickey & 232.66 & 14.37 & 0.375 & 0.311 & 0.309 \\
\hline Johnny Cueto & 217.00 & 15.89 & 0.360 & 0.306 & 0.268 \\
\hline Cole Hamels & 215.33 & 15.40 & 0.328 & 0.303 & 0.304 \\
\hline CC Sabathia & 200.00 & 15.14 & 0.296 & 0.300 & 0.308 \\
\hline Matt Cain & 219.33 & 15.25 & 0.358 & 0.294 & 0.271 \\
\hline James Shields & 227.67 & 15.89 & 0.284 & 0.288 & 0.307 \\
\hline $\begin{array}{l}\text { Madison } \\
\text { Bumgarner }\end{array}$ & 208.33 & 15.69 & 0.297 & 0.286 & 0.289 \\
\hline Kyle Lohse & 211.00 & 14.82 & 0.350 & 0.285 & 0.242 \\
\hline A.J. Burnett & 202.33 & 15.03 & 0.285 & 0.284 & 0.287 \\
\hline Jake Peavy & 219.00 & 15.92 & 0.297 & 0.268 & 0.270 \\
\hline Mat Latos & 209.33 & 15.63 & 0.287 & 0.260 & 0.262 \\
\hline Hiroki Kuroda & 219.67 & 15.16 & 0.301 & 0.259 & 0.268 \\
\hline Yovani Gallardo & 204.00 & 17.05 & 0.273 & 0.254 & 0.266 \\
\hline Wandy Rodriguez & 203.67 & 15.57 & 0.263 & 0.253 & 0.234 \\
\hline Homer Bailey & 208.00 & 16.03 & 0.272 & 0.252 & 0.255 \\
\hline Matt Harrison & 213.33 & 15.22 & 0.304 & 0.248 & 0.230 \\
\hline C.J. Wilson & 202.33 & 17.01 & 0.261 & 0.248 & 0.235 \\
\hline Ian Kennedy & 208.33 & 16.22 & 0.249 & 0.248 & 0.258 \\
\hline Bronson Arroyo & 202.00 & 14.64 & 0.267 & 0.245 & 0.235 \\
\hline Jon Lester & 205.33 & 16.68 & 0.207 & 0.243 & 0.249 \\
\hline Justin Masterson & 206.33 & 16.60 & 0.203 & 0.240 & 0.236 \\
\hline Mark Buehrle & 202.33 & 15.13 & 0.267 & 0.239 & 0.229 \\
\hline Clayton Richard & 218.67 & 14.48 & 0.251 & 0.216 & 0.233 \\
\hline Jason Vargas & 217.33 & 15.43 & 0.260 & 0.213 & 0.224 \\
\hline
\end{tabular}


2012 Overview of DMUs

\begin{tabular}{|c|c|c|c|}
\hline DMUs & Overall Efficiency & Scale Efficiency & Technical Efficiency \\
\hline Felix Hernandez & 1 & 1 & 1 \\
\hline Clayton Kershaw & 1 & 1 & 1 \\
\hline Justin Verlander & 0.945 & 0.987 & 0.958 \\
\hline David Price & 1 & 1 & 1 \\
\hline Zack Greinke & 0.979 & 0.980 & 0.998 \\
\hline Cliff Lee & 1 & 1 & 1 \\
\hline R.A. Dickey & 1 & 1 & 1 \\
\hline Johnny Cueto & 0.911 & 0.917 & 0.993 \\
\hline Cole Hamels & 0.932 & 0.951 & 0.981 \\
\hline CC Sabathia & 0.997 & 1 & 0.997 \\
\hline Matt Cain & 0.920 & 0.930 & 0.990 \\
\hline James Shields & 0.873 & 0.942 & 0.927 \\
\hline Madison Bumgarner & 0.907 & 0.908 & 0.999 \\
\hline Kyle Lohse & 0.930 & 1 & 0.930 \\
\hline A.J. Burnett & 0.925 & 0.949 & 0.974 \\
\hline Jake Peavy & 0.816 & 0.847 & 0.963 \\
\hline Mat Latos & 0.828 & 0.829 & 0.999 \\
\hline Hiroki Kuroda & 0.836 & 0.845 & 0.988 \\
\hline Yovani Gallardo & 0.852 & 0.855 & 0.997 \\
\hline Wandy Rodriguez & 0.799 & 0.818 & 0.977 \\
\hline Homer Bailey & 0.807 & 0.808 & 0.999 \\
\hline Matt Harrison & 0.791 & 0.818 & 0.967 \\
\hline C.J. Wilson & 0.789 & 0.826 & 0.956 \\
\hline Ian Kennedy & 0.802 & 0.802 & 0.999 \\
\hline Bronson Arroyo & 0.788 & 1 & 0.788 \\
\hline Jon Lester & 0.785 & 0.786 & 0.998 \\
\hline Justin Masterson & 0.759 & 0.761 & 0.997 \\
\hline Mark Buehrle & 0.764 & 0.862 & 0.886 \\
\hline Clayton Richard & 0.737 & 1 & 0.737 \\
\hline Jason Vargas & 0.702 & 0.710 & 0.988 \\
\hline
\end{tabular}


Stats of MLB 2013 season's starting pitchers

\begin{tabular}{|c|c|c|c|c|c|}
\hline DMUs & IP & $\mathrm{P} / \mathrm{IP}$ & 1/ERA & 1/FIP & 1/SIERA \\
\hline Clayton Kershaw & 236.00 & 14.53 & 0.546 & 0.418 & 0.334 \\
\hline Adam Wainwright & 241.67 & 14.62 & 0.340 & 0.392 & 0.340 \\
\hline Felix Hernandez & 204.33 & 15.54 & 0.329 & 0.383 & 0.361 \\
\hline Max Scherzer & 214.33 & 15.81 & 0.345 & 0.365 & 0.344 \\
\hline Cliff Lee & 222.67 & 14.61 & 0.348 & 0.355 & 0.353 \\
\hline Madison Bumgarner & 201.33 & 15.91 & 0.361 & 0.328 & 0.300 \\
\hline Mat Latos & 210.67 & 15.37 & 0.316 & 0.323 & 0.279 \\
\hline Chris Sale & 214.33 & 15.15 & 0.326 & 0.315 & 0.346 \\
\hline Cole Hamels & 220.00 & 15.56 & 0.278 & 0.307 & 0.293 \\
\hline Doug Fister & 207.67 & 16.07 & 0.272 & 0.306 & 0.292 \\
\hline Yu Darvish & 209.67 & 16.46 & 0.353 & 0.305 & 0.362 \\
\hline Justin Verlander & 218.33 & 16.91 & 0.289 & 0.305 & 0.277 \\
\hline Lance Lynn & 201.67 & 16.62 & 0.252 & 0.305 & 0.272 \\
\hline Homer Bailey & 209.00 & 15.75 & 0.287 & 0.302 & 0.301 \\
\hline Jordan Zimmermann & 213.33 & 14.45 & 0.308 & 0.298 & 0.278 \\
\hline Mike Minor & 204.67 & 15.27 & 0.312 & 0.297 & 0.281 \\
\hline Patrick Corbin & 208.33 & 14.79 & 0.293 & 0.292 & 0.281 \\
\hline Hisashi Iwakuma & 219.67 & 14.12 & 0.376 & 0.291 & 0.300 \\
\hline Derek Holland & 213.00 & 15.40 & 0.292 & 0.291 & 0.267 \\
\hline James Shields & 228.67 & 15.99 & 0.317 & 0.288 & 0.265 \\
\hline C.J. Wilson & 212.33 & 17.19 & 0.295 & 0.285 & 0.249 \\
\hline Eric Stults & 203.67 & 15.88 & 0.254 & 0.283 & 0.238 \\
\hline Hiroki Kuroda & 201.33 & 15.90 & 0.302 & 0.281 & 0.269 \\
\hline Jon Lester & 213.33 & 16.68 & 0.267 & 0.279 & 0.256 \\
\hline Jeff Samardzija & 213.67 & 16.20 & 0.230 & 0.265 & 0.283 \\
\hline Jose Quintana & 200.00 & 16.68 & 0.285 & 0.262 & 0.260 \\
\hline Travis Wood & 200.00 & 15.45 & 0.322 & 0.257 & 0.226 \\
\hline Ervin Santana & 211.00 & 15.16 & 0.309 & 0.254 & 0.265 \\
\hline Wade Miley & 202.67 & 15.98 & 0.282 & 0.251 & 0.253 \\
\hline Mark Buehrle & 203.67 & 16.20 & 0.241 & 0.244 & 0.242 \\
\hline CC Sabathia & 211.00 & 15.81 & 0.209 & 0.244 & 0.258 \\
\hline Chris Tillman & 206.33 & 16.85 & 0.270 & 0.226 & 0.258 \\
\hline Bronson Arroyo & 202.00 & 14.22 & 0.264 & 0.223 & 0.245 \\
\hline A.J. Griffin & 200.00 & 16.06 & 0.261 & 0.220 & 0.254 \\
\hline R.A. Dickey & 224.67 & 15.60 & 0.238 & 0.218 & 0.244 \\
\hline Jeremy Guthrie & 211.67 & 15.92 & 0.248 & 0.209 & 0.212 \\
\hline
\end{tabular}


2013 Overview of DMUs (a)

\begin{tabular}{|c|c|c|c|}
\hline DMUs & Overall Efficiency & Scale Efficiency & Technical Efficiency \\
\hline Clayton Kershaw & 1 & 1 & 1 \\
\hline Adam Wainwright & 0.992 & 0.994 & 0.998 \\
\hline Felix Hernandez & 1 & 1 & 1 \\
\hline Max Scherzer & 0.938 & 0.962 & 0.975 \\
\hline Cliff Lee & 1 & 1 & 1 \\
\hline Madison Bumgarner & 0.828 & 1 & 0.928 \\
\hline Mat Latos & 0.831 & 0.838 & 0.991 \\
\hline Chris Sale & 0.965 & 0.967 & 0.997 \\
\hline Cole Hamels & 0.798 & 0.814 & 0.980 \\
\hline Doug Fister & 0.801 & 0.810 & 0.989 \\
\hline Yu Darvish & 0.999 & 1 & 0.999 \\
\hline Justin Verlander & 0.754 & 0.780 & 0.966 \\
\hline Lance Lynn & 0.807 & 0.913 & 0.884 \\
\hline Homer Bailey & 0.827 & 0.835 & 0.990 \\
\hline Jordan Zimmermann & 0.816 & 0.986 & 0.828 \\
\hline Mike Minor & 0.830 & 0.921 & 0.901 \\
\hline Patrick Corbin & 0.812 & 0.921 & 0.882 \\
\hline Hisashi Iwakuma & 0.900 & 1 & 0.900 \\
\hline Derek Holland & 0.754 & 0.754 & 1 \\
\hline James Shields & 0.720 & 0.756 & 0.953 \\
\hline C.J. Wilson & 0.733 & 0.748 & 0.980 \\
\hline Eric Stults & 0.745 & 0.763 & 0.976 \\
\hline Hiroki Kuroda & 0.811 & 0.898 & 0.903 \\
\hline Jon Lester & 0.710 & 0.719 & 0.987 \\
\hline Jeff Samardzija & 0.751 & 0.783 & 0.960 \\
\hline Jose Quintana & 0.783 & 1 & 0.783 \\
\hline Travis Wood & 0.752 & 1 & 0.752 \\
\hline Ervin Santana & 0.773 & 0.819 & 0.944 \\
\hline Wade Miley & 0.756 & 0.796 & 0.950 \\
\hline Mark Buehrle & 0.692 & 0.708 & 0.978 \\
\hline CC Sabathia & 0.700 & 0.714 & 0.980 \\
\hline Chris Tillman & 0.741 & 0.755 & 0.980 \\
\hline Bronson Arroyo & 0.738 & 1 & 0.738 \\
\hline A.J. Griffin & 0.748 & 1 & 0.748 \\
\hline R.A. Dickey & 0.659 & 0.680 & 0.969 \\
\hline
\end{tabular}


2013 Overview of DMUs (b)

\begin{tabular}{cccc}
\hline DMUs & $\begin{array}{c}\text { Overall } \\
\text { Efficiency }\end{array}$ & $\begin{array}{c}\text { Scale } \\
\text { Efficiency }\end{array}$ & $\begin{array}{c}\text { Technical } \\
\text { Efficiency }\end{array}$ \\
\hline Jeremy Guthrie & 0.617 & 0.629 & 0.981 \\
\hline
\end{tabular}


Stats of MLB 2014 Season's Starting Pitchers

\begin{tabular}{|c|c|c|c|c|c|}
\hline DMUs & IP & $\mathrm{P} / \mathrm{IP}$ & 1/ERA & 1/FIP & 1/SIERA \\
\hline Corey Kluber & 235.67 & 14.85 & 0.410 & 0.426 & 0.383 \\
\hline Felix Hernandez & 236.00 & 14.55 & 0.467 & 0.391 & 0.400 \\
\hline Phil Hughes & 209.67 & 14.53 & 0.284 & 0.377 & 0.315 \\
\hline David Price & 248.33 & 15.02 & 0.307 & 0.360 & 0.368 \\
\hline Jon Lester & 219.67 & 15.90 & 0.407 & 0.357 & 0.324 \\
\hline Jose Quintana & 200.33 & 16.70 & 0.301 & 0.356 & 0.286 \\
\hline Max Scherzer & 220.33 & 16.51 & 0.317 & 0.351 & 0.336 \\
\hline Adam Wainwright & 227.00 & 14.35 & 0.420 & 0.347 & 0.284 \\
\hline Stephen Strasburg & 215.00 & 15.33 & 0.318 & 0.340 & 0.379 \\
\hline Zack Greinke & 202.33 & 15.87 & 0.369 & 0.337 & 0.348 \\
\hline Madison Bumgarner & 217.33 & 15.52 & 0.336 & 0.328 & 0.336 \\
\hline Cole Hamels & 204.67 & 15.32 & 0.407 & 0.326 & 0.304 \\
\hline Jeff Samardzija & 219.67 & 15.20 & 0.334 & 0.313 & 0.327 \\
\hline Dallas Keuchel & 200.00 & 15.10 & 0.341 & 0.312 & 0.322 \\
\hline Ian Kennedy & 201.00 & 16.93 & 0.275 & 0.312 & 0.288 \\
\hline Johnny Cueto & 243.67 & 15.02 & 0.444 & 0.303 & 0.317 \\
\hline Lance Lynn & 203.67 & 16.94 & 0.365 & 0.299 & 0.260 \\
\hline Sonny Gray & 219.00 & 15.05 & 0.325 & 0.289 & 0.281 \\
\hline Julio Teheran & 221.00 & 14.80 & 0.346 & 0.287 & 0.272 \\
\hline Aaron Harang & 204.33 & 16.61 & 0.280 & 0.280 & 0.239 \\
\hline Bartolo Colon & 202.33 & 14.88 & 0.244 & 0.280 & 0.267 \\
\hline James Shields & 227.00 & 16.00 & 0.312 & 0.279 & 0.279 \\
\hline Rick Porcello & 202.67 & 14.90 & 0.292 & 0.274 & 0.260 \\
\hline Mark Buehrle & 202.00 & 15.26 & 0.295 & 0.273 & 0.231 \\
\hline Justin Verlander & 206.00 & 16.55 & 0.220 & 0.267 & 0.240 \\
\hline Mike Leake & 214.33 & 15.00 & 0.270 & 0.258 & 0.285 \\
\hline Wade Miley & 201.33 & 15.98 & 0.230 & 0.251 & 0.272 \\
\hline Chris Tillman & 207.33 & 16.45 & 0.299 & 0.249 & 0.235 \\
\hline Jake Peavy & 202.67 & 15.91 & 0.268 & 0.243 & 0.243 \\
\hline A.J. Burnett & 213.67 & 16.25 & 0.218 & 0.242 & 0.250 \\
\hline Jered Weaver & 213.33 & 15.71 & 0.279 & 0.239 & 0.239 \\
\hline R.A. Dickey & 215.67 & 16.29 & 0.270 & 0.231 & 0.245 \\
\hline Jeremy Guthrie & 202.67 & 15.96 & 0.242 & 0.231 & 0.230 \\
\hline
\end{tabular}


2014 Overview of DMUs

\begin{tabular}{|c|c|c|c|}
\hline DMUs & Overall Efficiency & Scale Efficiency & Technical Efficiency \\
\hline Corey Kluber & 1 & 1 & 1 \\
\hline Felix Hernandez & 1 & 1 & 1 \\
\hline Phil Hughes & 0.995 & 1 & 0.995 \\
\hline David Price & 0.892 & 0.920 & 0.969 \\
\hline Jon Lester & 0.962 & 0.971 & 0.990 \\
\hline Jose Quintana & 0.983 & 1 & 0.983 \\
\hline Max Scherzer & 0.914 & 0.914 & 1 \\
\hline Adam Wainwright & 0.934 & 1 & 0.934 \\
\hline Stephen Strasburg & 1 & 1 & 1 \\
\hline Zack Greinke & 1 & 1 & 1 \\
\hline Madison Bumgarner & 0.904 & 0.904 & 0.999 \\
\hline Cole Hamels & 1 & 1 & 1 \\
\hline Jeff Samardzija & 0.866 & 0.866 & 1 \\
\hline Dallas Keuchel & 0.938 & 1 & 0.938 \\
\hline Ian Kennedy & 0.872 & 0.914 & 0.954 \\
\hline Johnny Cueto & 0.921 & 0.951 & 0.969 \\
\hline Lance Lynn & 0.903 & 0.929 & 0.972 \\
\hline Sonny Gray & 0.777 & 0.790 & 0.983 \\
\hline Julio Teheran & 0.790 & 0.810 & 0.976 \\
\hline Aaron Harang & 0.769 & 0.799 & 0.962 \\
\hline Bartolo Colon & 0.792 & 1 & 0.792 \\
\hline James Shields & 0.728 & 0.728 & 1 \\
\hline Rick Porcello & 0.778 & 1 & 0.778 \\
\hline Mark Buehrle & 0.782 & 0.839 & 0.932 \\
\hline Justin Verlander & 0.717 & 0.741 & 0.967 \\
\hline Mike Leake & 0.764 & 0.793 & 0.964 \\
\hline Wade Miley & 0.773 & 0.808 & 0.958 \\
\hline Chris Tillman & 0.728 & 0.741 & 0.983 \\
\hline Jake Peavy & 0.709 & 0.721 & 0.983 \\
\hline A.J. Burnett & 0.681 & 0.681 & 0.999 \\
\hline Jered Weaver & 0.670 & 0.681 & 0.983 \\
\hline R.A. Dickey & 0.664 & 0.664 & 1 \\
\hline Jeremy Guthrie & 0.669 & 0.676 & 0.990 \\
\hline
\end{tabular}

